\title{
Phytoprotection
}

\section{Pathogenicity of Pratylenchus penetrans to dwarfing apple rootstocks}

\section{La pathénogénicité du Pratylenchus penetrans sur des porte-greffes nains du pommier}

\section{Guy Bélair, Nathalie Dauphinais et Yvon Fournier}

Volume 99, numéro 1, 2019

URI : https://id.erudit.org/iderudit/1059304ar

DOI : https://doi.org/10.7202/1059304ar

Aller au sommaire du numéro

Éditeur(s)

Société de protection des plantes du Québec (SPPQ)

ISSN

1710-1603 (numérique)

Découvrir la revue

Citer cet article

Bélair, G., Dauphinais, N. \& Fournier, Y. (2019). Pathogenicity of Pratylenchus penetrans to dwarfing apple rootstocks. Phytoprotection, 99(1), 12-14. https://doi.org/10.7202/1059304ar
Résumé de l'article

L'objectif de cette recherche était de mesurer l'effet des densités de $P$. penetrans sur la croissance végétative de trois porte-greffes nains, Bud 9, M.9 et M.26 dans des conditions de microparcelle au champ. Soumis à une densité initiale de 500 nématodes $\mathrm{kg}^{-1}$ de sol, les poids secs de nouvelles pousses des porte-greffes Bud 9, M.9 et M.26 ont été réduits de manière significative respectivement de $30 \%, 23 \%$ et $14 \%$. Soumis à une densité initiale de 1 500nématodes $\mathrm{kg}^{-1}$ de sol, les poids secs de Bud 9 et M.9 n'étaient pas significativement différents de ceux exposés à 500 nématodes $\mathrm{kg}^{-1} \mathrm{de}$ sol, à l'exception de M.26 qui affichait une diminution de $29 \%$. Le poids sec des racines des porte-greffes n'a pas été réduit de manière significative lorsqu'ils ont été exposés à ces densités de $P$. penetrans, à l'exception de M.26, qui a été réduit de $26 \%$ lorsqu'exposé à la densité de 1500 nématodes $\mathrm{kg}^{-1}$ de sol. Ces résultats confirment l'effet pathogène de $P$. penetrans sur les porte-greffes nains. Ces résultats préliminaires suggèrent une tolérance de M.26 à $P$. penetrans sous la densité de 500 nématodes $\mathrm{kg}^{-1}$ de sol. Sous la densité de 1500 nématodes $\mathrm{kg}^{-1}$ de sol, les Bud 9 et M.9 présentaient tous deux une tolérance de leur système racinaire comparativement à M.26. Ces résultats soulignent également l'importance de poursuivre l'évaluation de la sensibilité/tolérance des porte-greffes nains aux diverses densités du P. penetrans. 


\title{
Pathogenicity of Pratylenchus penetrans to dwarfing apple rootstocks
}

\author{
Guy Bélair ${ }^{\bowtie}$, Nathalie Dauphinais and Yvon Fournier
}

Received 2017-11-08; accepted 2018-02-15

PHYTOPROTECTION 99 : 12-14

The objective of this research was to measure the effect of $P$. penetrans densities on the vegetative growth of three apple dwarfing rootstocks Bud 9, M.9 and M.26 under field microplot conditions. Under 500 nematodes kg ${ }^{-1}$ soil density, the shoot dry weights of Bud 9, M.9 and M.26 rootstocks were significantly reduced by $30 \%, 23 \%$ and $14 \%$ respectively. Under the 1500 nematodes $\mathrm{kg}^{-1}$ soil density, the dry shoot weight of Bud 9 and M.9 were not significantly different from the 500 nematodes $\mathrm{kg}^{-1}$ soil density except M.26 which exhibited a $29 \%$ decrease. The root dry weights of rootstocks were not significantly reduced when exposed to these P. penetrans densities except M.26 which was reduced $26 \%$ relative to non-inoculated trees under the 1500 nematodes $\mathrm{kg}^{-1}$ soil density. These results confirm the pathogenic effect of $P$. penetrans on dwarfing apple rootstocks. Although preliminary, these results suggest some tolerance of M.26 to P. penetrans under lower density when compared to M.9 and Bud 9. Under higher nematode densities, both Bud 9 and M.9 exhibited a tolerance of their root system in comparison to M.26. Our results also emphasize the need to further assess the susceptibility/tolerance of dwarfing apple rootstocks to various densities of $P$. penetrans.

Keywords: Pratylenchus penetrans, apple rootstock, nematode density.

\section{[La pathénogénicité du Pratylenchus penetrans sur des porte-greffes nains du pommier]}

L'objectif de cette recherche était de mesurer l'effet des densités de $P$. penetrans sur la croissance végétative de trois porte-greffes nains, Bud 9, M.9 et M.26 dans des conditions de microparcelle au champ. Soumis à une densité initiale de 500 nématodes $\mathrm{kg}^{-1}$ de sol, les poids secs de nouvelles pousses des porte-greffes Bud $9, \mathrm{M} .9$ et M.26 ont été réduits de manière significative respectivement de $30 \%, 23 \%$ et $14 \%$. Soumis à une densité initiale de 1500 nématodes $\mathrm{kg}^{-1}$ de sol, les poids secs de Bud 9 et M.9 n'étaient pas significativement différents de ceux exposés à 500 nématodes $\mathrm{kg}^{-1}$ de sol, à l'exception de M.26 qui affichait une diminution de $29 \%$. Le poids sec des racines des porte-greffes n'a pas été réduit de manière significative lorsqu'ils ont été exposés à ces densités de P. penetrans, à l'exception de M.26, qui a été réduit de $26 \%$ lorsqu'exposé à la densité de 1500 nématodes $\mathrm{kg}^{-1}$ de sol. Ces résultats confirment l'effet pathogène de $P$. penetrans sur les porte-greffes nains. Ces résultats préliminaires suggèrent une tolérance de $M .26$ à $P$. penetrans sous la densité de 500 nématodes $\mathrm{gg}^{-1}$ de sol. Sous la densité de 1500 nématodes $\mathrm{kg}^{-1}$ de sol, les Bud 9 et M.9 présentaient tous deux une tolérance de leur système racinaire comparativement à M.26. Ces résultats soulignent également l'importance de poursuivre l'évaluation de la sensibilité/tolérance des porte-greffes nains aux diverses densités du P. penetrans.

Mots clés : Pratylenchus penetrans, porte-greffe du pommier, densité de nématode. 
The root-lesion nematode (RLN) Pratylenchus penetrans is the dominant species parasitizing apple trees in eastern North America (Mai et al. 1970; Pitcher et al. 1960; Traquair 1984; Vrain and Rousselle 1980). This species is highly pathogenic to apple seedlings and associated with apple replant disease (Jaffee et al. 1982; Jaffee and Mai 1979). Parker and Mai (1974) reported that the level of damage varied among rootstocks. Currently, the standard practice of apple growers is to replant old sites with dwarf and semi-draft rootstocks immediately after pulling out the old orchards. Rootstocks have the advantage of being very precocious, with high yield efficiency (Webster 1993). This allows growers to change cultivars as necessary without extended periods of lost production. In Eastern Canada, winter hardiness is a primary criterion for the selection of dwarfing rootstocks. Because dwarfing rootstocks have a limited root volume and benefit from supplemental irrigation in dry seasons and in droughty soils, their susceptibility to RLN is suspected to vary with the soil densities at planting. In Quebec, RLN population densities at planting are highly variable but can reach several thousand per kg of soil (Vrain and Rousselle 1980). The main objective of this study was to measure the effect of RLN densities on vegetative growth of three apple dwarfing rootstocks under field microplot conditions.

The impact of three initial population densities of RLN on the vegetative growth of three apple rootstocks under field microplot conditions was studied at the experimental farm of Agriculture and Agri-Food Canada at L'Acadie, QC. Field microplots consisted of bottomless wood frames $(1 \mathrm{~m}$ wide $\times 2 \mathrm{~m}$ long $\times 0.2 \mathrm{~m}$ deep) buried in a loamy sand soil ( $82 \%$ sand, $10 \%$ silt, and $8 \%$ clay). Microplots were infested in 1998-1999 with a local isolate of $P$. penetrans from soil from Lavaltrie, QC and rye (Secale cereale) was grown for three consecutive years inside these same microplots to increase P. penetrans densities. No soil fumigation was performed prior to the initial inoculation. Eight control microplots (without nematode) were not infested and planted with marigold (Tagetes erecta) cv. Crackerjack to maintain low RLN soil densities.

The growth of three dwarfing apple rootstocks; Bud 9 (Budagovsky 9), M.9 (Malling 9) and M.26 (Malling 26) was evaluated under three initial nematode population density classes: no nematodes, medium (approx. 500 nematodes $\mathrm{kg}^{-1}$ soil), and high (approx. 1500 nematodes $\mathrm{kg}^{-1}$ soil). Based on counts of RLN kg-1 soil in fall of 2005, eight microplots were allocated to each of the three classes of initial nematode population densities. Actual means and ranges (min-max) for the medium and high population densities were $490 \mathrm{RLN} \mathrm{kg}^{-1}$ (450-540) and $1470 \mathrm{RLN} \mathrm{kg}^{-1}$ (1390-1620), respectively. Prior to planting, the soil was prepared with a motorized cultivator after adding in each microplot ON-46P-OK

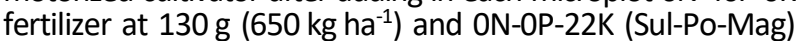

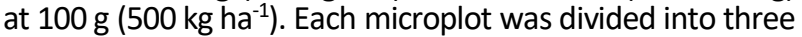
equal submicroplots of $1 \mathrm{~m}$ wide $x 67 \mathrm{~cm}$ long and one of the three genotypes was randomly allocated to each of submicroplots. Each apple rootstock was planted on two 1-m rows (three per row) (15-cm between plants and between rows).

Apple rootstocks (shoot diameter between $7 \mathrm{~mm}$ to $10 \mathrm{~mm}$ ) were purchased from the Boerboom Nursery Inc., St-Paul-D'Abbotsford, QC. Before planting, all plants were cut to $30 \mathrm{~cm}$ total length and roots were immerged for four hours in fertilizer solution 10N-52P-10K $\left(5 \mathrm{~g} \mathrm{~L}^{-1}\right)$. Holes of $15 \mathrm{~cm}$ deep and $5 \mathrm{~cm}$ diameter were dug. One rootstock was put in each hole and then filled with $500 \mathrm{ml}$ of PRO-MIX BX from Premier Tech, Rivière-du-Loup, QC. (a general purpose peat-based growing medium with vermiculite and perlite) mixed with $10 \mathrm{~N}-52 \mathrm{P}-10 \mathrm{~K}$ fertilizer (216 L of Pro-mix mixed with $36 \mathrm{~L}$ of $\left.10 \mathrm{~N}-52 \mathrm{P}-10 \mathrm{~K}\left[5 \mathrm{~g} \mathrm{~L}^{-1}\right]\right)$. All apple rootstocks were planted on 20 April 2006 and were watered after planting. All microplots were fertilized on 4 May with $3.5 \mathrm{~L}$ of $10 \mathrm{~N}-52 \mathrm{P}-10 \mathrm{~K}$ fertilizer $\left(5 \mathrm{~g} \mathrm{~L}^{-1}\right)$ and on 23 May with $4 \mathrm{~L}$ of $20 \mathrm{~N}-20 \mathrm{P}-20 \mathrm{~K}$ $\left(1 \mathrm{~g} \mathrm{~L}^{-1}\right)$. Weeds were controlled by hand weeding several times during the season.

Table 1. Effect of $\boldsymbol{P}$. penetrans on growth of three dwarfing apple rootstocks

\begin{tabular}{|c|c|c|c|c|c|c|}
\hline \multirow[b]{3}{*}{ Rootstock } & \multicolumn{4}{|c|}{ Growth } & \multicolumn{2}{|c|}{ P. penetrans densities } \\
\hline & \multicolumn{2}{|c|}{ Root dry weight } & \multicolumn{2}{|c|}{ Shoot dry weight } & \multirow{2}{*}{$\frac{\text { Spring }}{\text { (/kg soil) }}$} & \multirow{2}{*}{$\frac{\text { Fall }}{\text { (/kg soil) }}$} \\
\hline & (g) & (\% check) & (g) & (\% check) & & \\
\hline Bud $9-\mathrm{NI}^{*}$ & $8.2 a^{* *}$ & & $70.1 \mathrm{a}$ & & $0 \mathrm{c}$ & $40 \mathrm{~b}$ \\
\hline Bud 9 - Med & $7.2 \mathrm{a}$ & -12 & $49.2 \mathrm{~b}$ & -30 & $237 b$ & $1846 a$ \\
\hline Bud 9 - High & $8.0 \mathrm{a}$ & -2 & $45.0 \mathrm{~b}$ & -36 & 475 a & 5130 a \\
\hline M.9- NI & $6.5 a$ & & $56.6 \mathrm{a}$ & & $8 c$ & $2 \mathrm{~b}$ \\
\hline M.9 - Med & $6.0 \mathrm{a}$ & -8 & $43.6 \mathrm{~b}$ & -23 & $92 \mathrm{~b}$ & 2387 a \\
\hline M.9 - High & 5.9 a & -9 & $42.4 \mathrm{~b}$ & -25 & 485 a & $2047 a$ \\
\hline M.26 - NI & $8.6 \mathrm{a}$ & & $62.2 \mathrm{a}$ & & $0 \mathrm{c}$ & $12 \mathrm{~b}$ \\
\hline M.26 - Med & $8.2 \mathrm{ab}$ & -5 & $53.3 b$ & -14 & $202 b$ & 3406 a \\
\hline M.26 - High & $6.6 \mathrm{~b}$ & -23 & $44.1 \mathrm{c}$ & -29 & 588 a & $3204 a$ \\
\hline
\end{tabular}

* Initial RLN density class: $\mathrm{NI}=$ non-inoculated or approx. 0 RLN kg-1 soil, Med $=500 \mathrm{RLN} \mathrm{kg}^{-1}$ soil, High $=1500 \mathrm{RLN} \mathrm{kg}{ }^{-1}$ soil based on fall 2005 average population densities.

** Values within the same column (rootstock) followed by the same letter are not significantly different (ANOVA, $p \leq 0.05)$ Tukey's test. 
On 3 October 2006, the shoot and the root of all rootstocks were harvested. The shoots were chopped in $5-\mathrm{cm}$ pieces, oven-dried $\left(70^{\circ} \mathrm{C}\right)$ for two days and weighed to record the average shoot weight per rootstock-nematode treatment. The root system of three randomly selected plants per experimental unit was washed under running tap water, oven-dried $\left(70^{\circ} \mathrm{C}\right)$ for two days, and weighed to determine the average root weight per rootstock-nematode treatment. Soil samples from each submicroplot were collected to determine the number of RLN before planting on 24 May and at harvest on 3 October 2006. Four soil cores $(5 \mathrm{~cm} \times 20 \mathrm{~cm})$ per submicroplot (apple rootstock) were composited into one sample representing the submicroplot. Nematodes were extracted from a $50-\mathrm{cm}^{3}$ subsample from each composite sample by the modified Baermann pan method (Townshend 1963). Nematodes were counted using a stereo-microscope and expressed as numbers per $\mathrm{kg}$ of soil.

The shoot dry weights of Bud 9, M.9 and M.26 rootstocks were significantly reduced under the medium initial population density by $30 \%, 23 \%$ and $14 \%$ respectively (ANOVA, $p \leq 0.05$ ) (Table 1). Under the high initial population density, the shoot dry weights of Bud 9 and M.9 were not significantly different from the medium initial population density except M.26 which exhibited a $29 \%$ decrease between the medium and high initial population densities (ANOVA, $p \leq 0.05$ ). The root dry weights of rootstocks were not significantly reduced when exposed to either initial population densities except M.26 which was reduced $26 \%$ relative to non-inoculated trees at the high density (ANOVA, $p \leq 0.05$ ). In May and October 2006, RLN densities were significantly different from the control (ANOVA, $p \leq 0.05$ ).

These results confirm the pathogenic effect of RLN on dwarfing apple rootstocks under field microplot conditions. But we need to acknowledge the fact that growth of marigold could have had other effects besides keeping RLN densities low (e.g. other root pathogens, beneficial rhizosphere organisms, nutrient availability, etc.). Based on previous experiments performed in these same microplots over the years, our database does not support this hypothesis.

Although preliminary, these results suggest some tolerance of M.26 to RLN under lower density when compared to M.9 and Bud 9. Under higher nematode densities, both Bud 9 and M.9 exhibited a tolerance of their root system in comparison to M.26. Now, it has been previously demonstrated that the pathogenicity of RLN on apple will be affected by seeding age (Jaffe and Mai 1979). Because the root-lesion nematode feeds on the small rootlets and thus decreases the normal uptake of water and nutrients, the growth of dwarfing rootstocks could be more inclined to be affected during the establishment years. Thus, it would be safer to provide adequate moisture during this critical period. Our results emphasize the need to further assess the susceptibility/ tolerance of dwarfing apple rootstocks to various RLN population densities.

\section{REFERENCES}

Jaffee, B.A., G.S. Abawi, and W.F. Mai. 1982. Role of soil microflora and Pratylenchus penetrans in an apple replant disease. Phytopathology 72 : 247-251.

Jaffee, B.A., and W.F. Mai. 1979. Growth of apple seedlings by Pratylenchus penetrans as influenced by seedling age at inoculation. J. Nematol. $11: 161-165$.

Mai, W.F., K.G. Parker, and K.D. Hickey. 1970. Populations of Pratylenchus penetrans and growth of apple in response to soil treatment with nematicides. Plant Dis. Rep. 54 : 792-795.

Pitcher, R.S., Z.A. Patrick, and W.B. Mountain. 1960. Studies on the host-parasite relations of Pratylenchus penetrans (Cobb) to apple seedlings I. Pathogenicity under sterile conditions. Nematologica 5 : 309-314.

Townshend, J.L. 1963. A modification and evaluation of the apparatus for the Oostenbrink direct cotton-wool filter extraction method. Nematologica 9 : 106-110.

Vrain, T.C., and G.L. Rousselle. 1980. Distribution of plantparasitic nematodes in Quebec apple orchards. Plant Dis. 64 : 582-583.

Parker, K.G., and W.F. Mai, 1974. Damage caused by Pratylenchus penetrans to apple trees in the orchard growing on different rootstocks. Plant Dis. Rep. 58: 1007-1011.

Traquair, J.A. 1984. Etiology and control of orchard replant problems: a review. Can. J. Plant Pathol. 6 : 54-62.

Webster, A.D. 1993. New dwarfing rootstocks for apple, pear plum and sweet cherry - a brief review. Acta Hortic. $349: 145-153$. 